\title{
Heat-Loss Testing of Solel's UVAC3 Parabolic Trough Receiver
}

Technical Report NREL/TP-550-42394 January 2008

F. Burkholder and C. Kutscher 


\title{
Heat-Loss Testing of Solel's UVAC3 Parabolic Trough Receiver
}

\section{Technical Report NREL/TP-550-42394 January 2008}

\author{
F. Burkholder and C. Kutscher
}

Prepared under Task No. CP07.3101

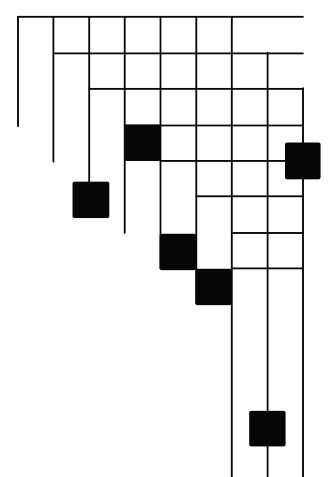




\section{NOTICE}

This report was prepared as an account of work sponsored by an agency of the United States government. Neither the United States government nor any agency thereof, nor any of their employees, makes any warranty, express or implied, or assumes any legal liability or responsibility for the accuracy, completeness, or usefulness of any information, apparatus, product, or process disclosed, or represents that its use would not infringe privately owned rights. Reference herein to any specific commercial product, process, or service by trade name, trademark, manufacturer, or otherwise does not necessarily constitute or imply its endorsement, recommendation, or favoring by the United States government or any agency thereof. The views and opinions of authors expressed herein do not necessarily state or reflect those of the United States government or any agency thereof.

Available electronically at http://www.osti.gov/bridge

Available for a processing fee to U.S. Department of Energy and its contractors, in paper, from:

U.S. Department of Energy

Office of Scientific and Technical Information

P.O. Box 62

Oak Ridge, TN 37831-0062

phone: 865.576 .8401

fax: 865.576 .5728

email: mailto:reports@adonis.osti.gov

Available for sale to the public, in paper, from:

U.S. Department of Commerce

National Technical Information Service

5285 Port Royal Road

Springfield, VA 22161

phone: 800.553.6847

fax: 703.605.6900

email: orders@ntis.fedworld.gov

online ordering: http://www.ntis.gov/ordering.htm 
TABLE OF CONTENTS

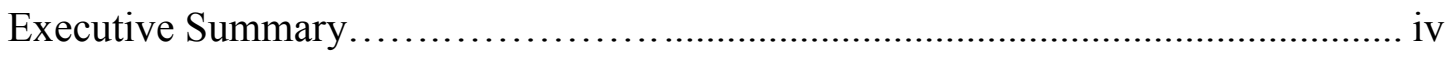

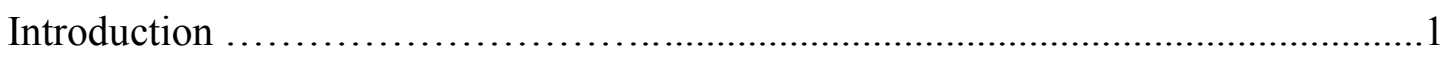

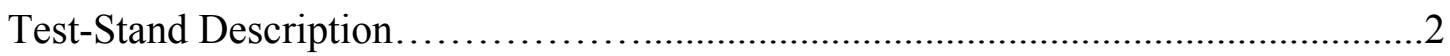

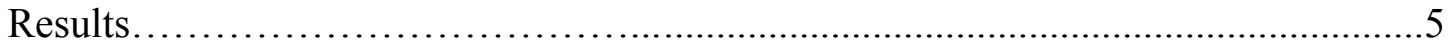

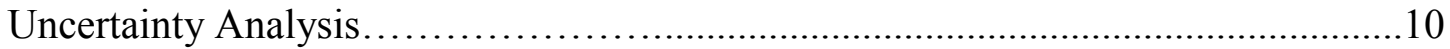

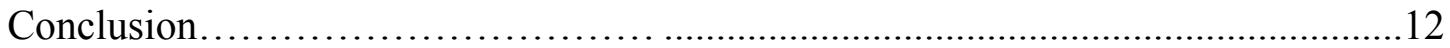

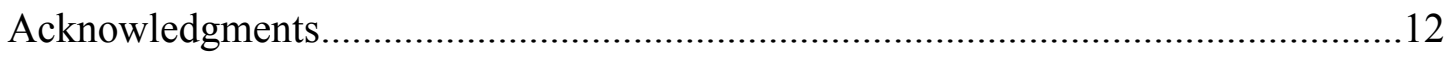

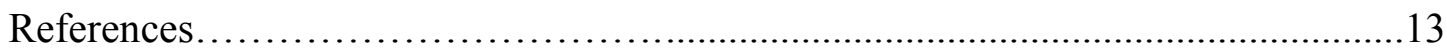




\section{EXECUTIVE SUMMARY}

Researchers at the National Renewable Energy Laboratory completed heat-loss testing on two of Solel's UVAC3 parabolic trough receivers. The receivers showed identical heat losses within experimental uncertainty. Normalized per meter of receiver length, heat losses are $130,200,310$, and $460 \mathrm{~W} / \mathrm{m}$ at average absorber temperatures of $300^{\circ}, 350^{\circ}, 400^{\circ}$, and $450^{\circ} \mathrm{C}$, respectively. Experimental uncertainty is about $\pm 10 \mathrm{~W} / \mathrm{m}$. A correlation was developed to predict receiver heat loss as a function of the difference in ${ }^{\circ} \mathrm{C}$ between the average absorber temperature and ambient temperature. This correlation is:

$$
\text { UVAC3 heat loss }(\mathrm{W} / \mathrm{m})=0.26 * \Delta \mathrm{T}+1.05 * 10^{-8} * \Delta \mathrm{T}^{4}
$$

Care must be taken to apply this correlation within context. The correlation was derived with ambient temperatures of about $23^{\circ} \mathrm{C}$, and it should not be used to predict heat losses at ambient temperatures more or less than $10^{\circ} \mathrm{C}$ from this value. This limitation is explained further in the report.

UVAC3 heat losses were compared to heat losses from UVAC2, the previous generation of receiver. The UVAC3 receiver shows significantly lower heat loss: $310 \mathrm{vs.} 380 \mathrm{~W} / \mathrm{m}$ at $400^{\circ} \mathrm{C}$, which is a $20 \%$ reduction in heat loss.

It is important to note that receiver performance depends on more than just heat losses. Optical efficiency testing is required to create a collector/receiver efficiency curve that estimates the heat gain to the heat-transfer fluid flowing within the receiver. Heat losses, as tested in this report, serve to reduce the heat gain to the heat-transfer fluid and therefore reduce the collector/receiver efficiency. 


\section{INTRODUCTION}

A parabolic trough power plant generates electricity using sunlight as the heat source for its power cycle. Rows of single-axis-tracking, linear parabolic mirrors comprise a solar field that concentrates sunlight onto tubular receivers (also known as heat-collection elements or HCEs) located along the focal line of each parabolic trough. Heat-transfer fluid pumped through the receivers is heated by convection from the sun-heated receiver walls. After being sufficiently heated by the solar field, this hot fluid travels to a power block, where it generates steam in a series of heat exchangers to run a Rankine steam-turbine power cycle. The fluid then returns to the solar field.

Figure 1 shows a section of the solar field of a parabolic trough power plant. This photograph comes from one of the nine Solar Electric Generating Systems (SEGS) built in California's Mojave Desert by Luz International Limited [1]. It illustrates the receivers (HCEs) and parabolic mirrors mounted on a supporting structure, which is collectively referred to as a collector.

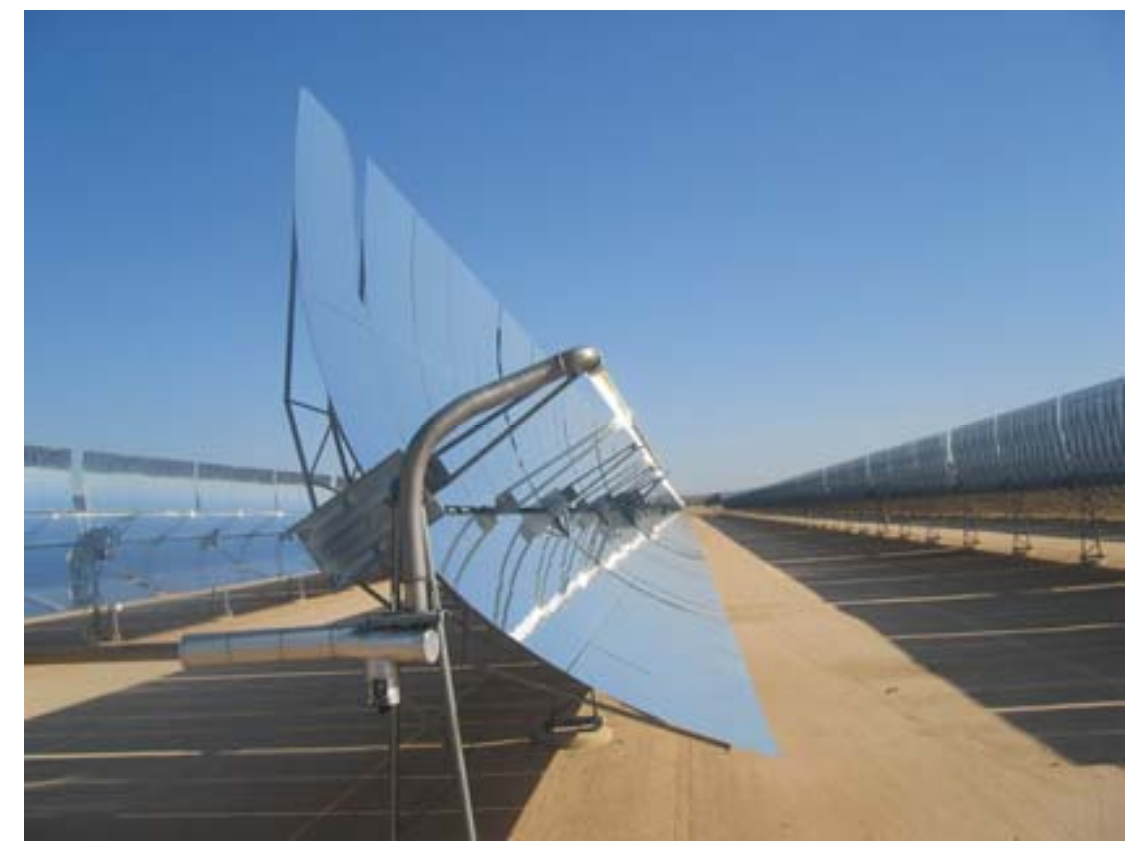

Figure 1. Mirrored trough collectors and receivers at a SEGS plant

The SEGS plants currently provide 354 megawatts (MW) to the Southern California Edison utility, and the latest plants operate at fluid temperatures of $293^{\circ}$ to $391^{\circ} \mathrm{C}$. At these temperatures, the heat losses from the receivers to ambient can significantly affect plant performance by decreasing the amount of heat gained by the internally circulating heattransfer fluid. 
Solel Solar Systems Ltd., based in Israel, manufactures the UVAC3 HCE and the previousgeneration UVAC2. This report presents heat-loss test results of two UVAC3 HCEs.

\section{TEST-STAND DESCRIPTION}

Figure 2 is a photograph of the National Renewable Energy Laboratory (NREL) HCE HeatLoss Test Stand. This test stand is located indoors and uses electric resistance heating on the inside of the HCE to bring the absorber surface up to desired test temperatures. Once a desired temperature is reached and the system comes to steady state, power transducers measure the electrical power required to maintain the absorber temperature. The power required is the heat loss of the HCE.

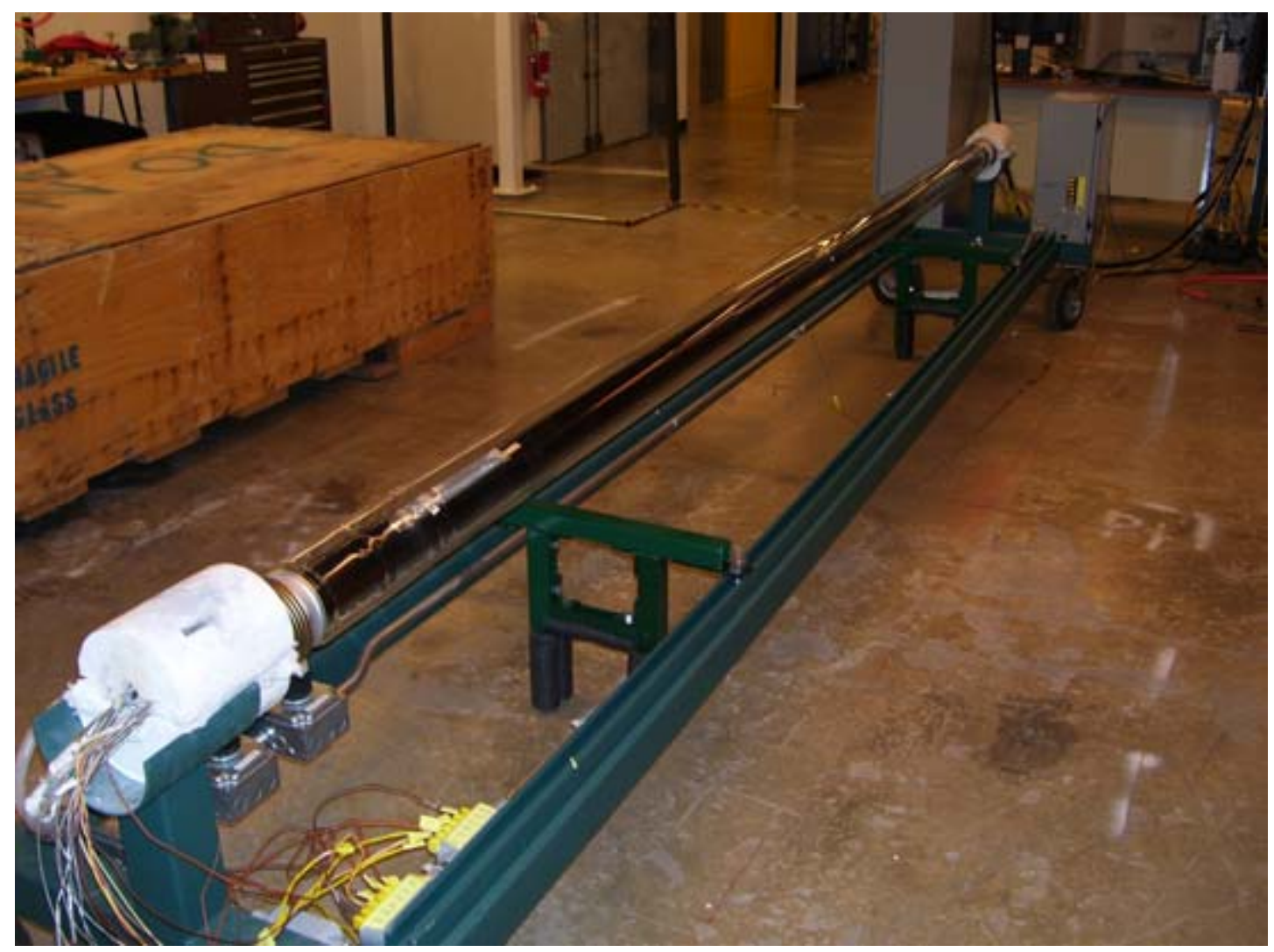

Figure 2. HCE heat-loss test stand at NREL

Present HCEs are $4.06 \mathrm{~m}$ long at $25^{\circ} \mathrm{C}\left(4.08 \mathrm{~m}\right.$ at $\left.400^{\circ} \mathrm{C}\right)$ with an absorber inner diameter of $6.6 \mathrm{~cm}$. To test HCE heat loss, two copper pipes $2.17 \mathrm{~m}$ long and with $5.4 \mathrm{~cm}$ outer diameter are inserted into the ends of an HCE - one copper pipe per end. Bolt heads protruding from the copper pipe surface center it in the HCE and prevent it from touching the inner absorber surface. The copper pipe evens out the temperature distribution generated by three internal electric resistance heaters. Two of the heaters are 3-cm-long, stainless-steel-sheathed, coiled cable heaters whose surfaces contact the interior of the copper pipe. We will refer to these heaters as "coil heaters" in this report. The third heater is a $2.12 \mathrm{~m}$ (2.01 m heated-length) 
inconel cartridge heater suspended along the cylindrical axis of the copper pipe using inconel spacers. The cartridge heater is fully inserted into the copper pipe so that its innermost end, shown in Figure 3, is flush with the innermost end of the copper pipe. The coil heaters are held in position on the cartridge heater by shrink-fitted inconel spacers. When the copper pipe is inserted into the HCE, one coil heater ends up just inside the HCE, whereas the other is adjacent to it but just outside the HCE. The innermost coil heater compensates for endloss effects, whereas the outermost coil heater is used to create an adiabatic boundary along the copper pipe between the two coil heaters. The cartridge heater supplies most of the thermal input to the system, especially at increasing absorber temperatures. Power transducers measure heater output. The total heat loss is based on the sum of the powers of the two innermost coil heaters and the two cartridge heaters. Figure 3 is a photograph of one of the two heater assemblies, and Table 1 lists heater and power transducer specifications.

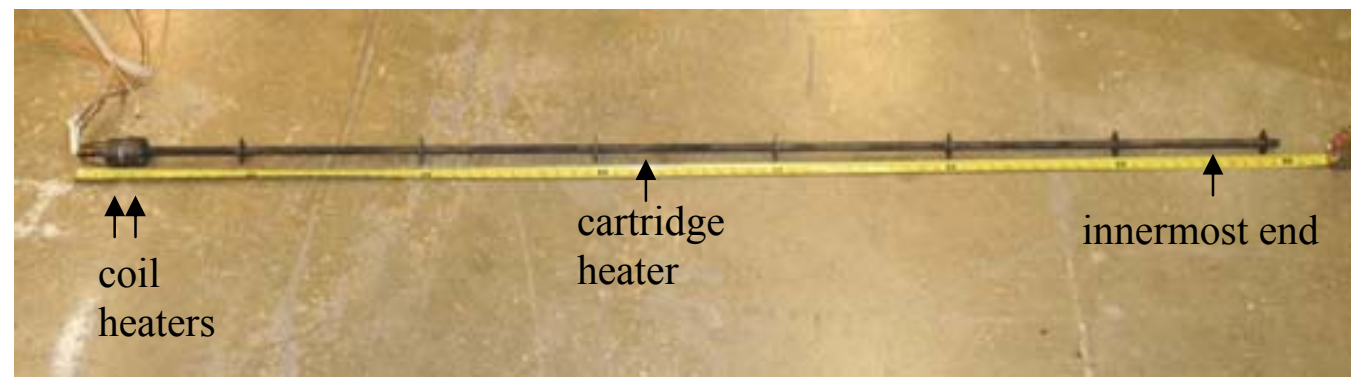

Figure 3. Heater assembly

Table 1. Heater and Power Transducer Specifications

\begin{tabular}{|c|c|c|c|c|c|}
\hline \multirow[b]{2}{*}{ Heater Type } & \multirow[b]{2}{*}{ \# Used } & \multirow[b]{2}{*}{$\begin{array}{l}\text { Max. Power of } \\
\text { each Heater (W) }\end{array}$} & \multirow[b]{2}{*}{$\begin{array}{l}\text { Transducer Full- } \\
\text { Scale Limit (W) }\end{array}$} & \multicolumn{2}{|c|}{ Error } \\
\hline & & & & $\begin{array}{c}\% \text { of } \\
\text { Full } \\
\text { Scale }\end{array}$ & (W) \\
\hline $\begin{array}{l}\text { Coiled cable } \\
\text { heater }\end{array}$ & 4 & 600 & 500 & 0.5 & 2.5 \\
\hline $\begin{array}{l}\text { Cartridge } \\
\text { heater }\end{array}$ & 2 & 4800 & 5000 & 0.5 & 25 \\
\hline
\end{tabular}

Thermocouples measure the temperature of the copper pipe, stainless-steel absorber, and glass at the locations shown in Fig. 4. The copper temperature is measured at four locations, the absorber at four locations, and the glass at one location. Figure 4 shows the heating assembly that is responsible for heating one half of the HCE. The heating assembly and thermocouple locations for the other half are identical and symmetrical about the HCE center line, with thermocouple naming conventions continuing from left to right though $\mathrm{Cu} 4$ and Abs4. The ends of the copper pipes touch when both heating assemblies are inserted into an HCE. 


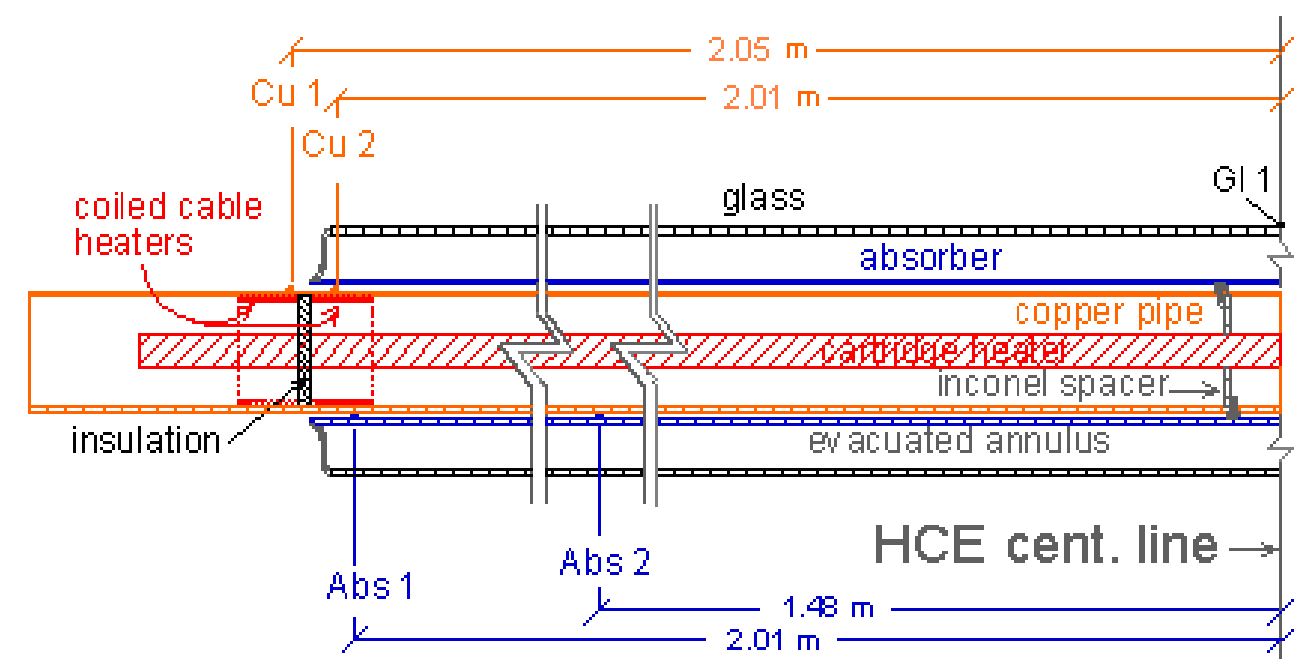

Figure 4. Copper (Cu), absorber (Abs), and glass (GI) thermocouple locations; absorber at $25^{\circ} \mathrm{C}$

Inconel, copper, and stainless steel have different linear expansion coefficients. Care must be taken to attach the copper and inconel at only one point to avoid thermal stresses. The center line of the HCE is the approximate location of this attachment, as shown in Fig. 4. Bolts thread through the copper pipe to rest on either side of an inconel spacer shrink-fitted to the end of the inconel cartridge heater. This is the point from which the inconel cartridge heater, copper pipe, and stainless-steel absorber expand outwards. At $400^{\circ} \mathrm{C}$, the outer edge of the absorber overlaps the insulation and almost overlaps the inner edge of the outermost coil heater, whereas thermocouples $\mathrm{Abs} 1, \mathrm{Cu} 1$, and $\mathrm{Cu} 2$ become better centered over their respective coil heaters.

Wires attach the thermocouples to the copper and glass surfaces. The thermocouples measuring absorber temperatures spring out from the copper pipe to contact the inner absorber surface. Reliable absorber temperature measurements require good contact between the thermocouple and the absorber, as well as local radiation shielding to prevent radiant heating of the thermocouple by the copper pipe. Figure 5 shows the shielding underneath one thermocouple used to measure absorber temperature, and Table 2 lists the thermocouple specifications. Thermocouples also measure air and heater temperatures.

Testing proceeds once the heating assemblies are in place and the HCE is supported in the test stand. Electrical power to the inner coil and cartridge heaters is increased slowly until all absorber temperatures approach a value of interest (e.g., $400^{\circ} \mathrm{C}$ ). The power to the outer coil heaters is adjusted so that the outer copper temperatures are equal to the inner copper temperatures (i.e., $\mathrm{Cu} 1=\mathrm{Cu} 2$ and $\mathrm{Cu} 3=\mathrm{Cu} 4$ ), creating adiabatic boundaries between $\mathrm{Cu} 1-$ $\mathrm{Cu} 2$ and $\mathrm{Cu} 3-\mathrm{Cu} 4$. Temperatures and power values are logged every 5 seconds. Steady state is achieved when heater set-points are not changed and the center-of-glass and absorber temperatures remain constant (variation $\leq 0.5^{\circ} \mathrm{C}$ ) over a period of at least 15 minutes. 


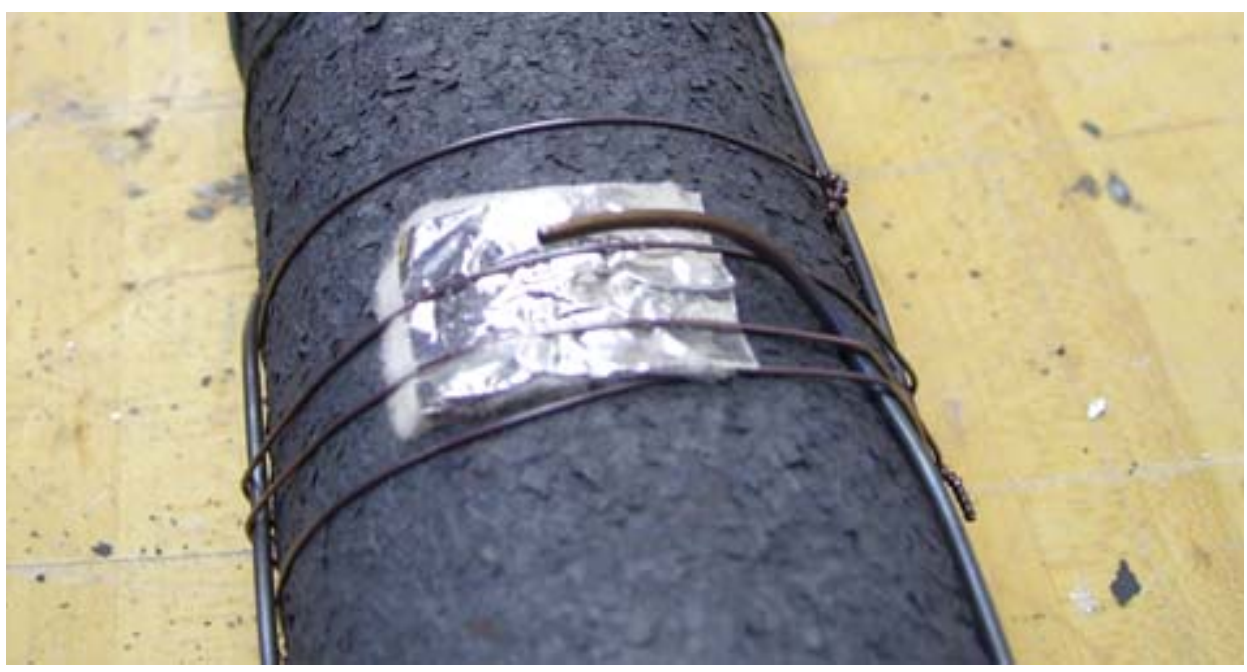

Figure 5. Absorber thermocouple with required radiant shielding on copper pipe

Table 2. Thermocouple Specifications

\begin{tabular}{|l|c|c|c|c|}
\hline \multicolumn{1}{|c|}{ Thermocouple Description } & \multirow{2}{*}{$\begin{array}{c}\text { Calibration } \\
\text { Type }\end{array}$} & $\begin{array}{c}\text { Range } \\
{ }^{\circ} \mathrm{C}\end{array}$ & \multicolumn{2}{|c|}{$\begin{array}{c}\text { Temperature Error } \\
\text { Maximum of: }\end{array}$} \\
\cline { 4 - 5 } & $\begin{array}{c}\% \text { of } \\
\text { Reading }\end{array}$ & ${ }^{\circ} \mathrm{C}$ \\
\hline $\begin{array}{l}\text { Alloy 600 sheath, mineral } \\
\text { insulated, AF metal transition, } \\
\text { ungrounded }\end{array}$ & $\begin{array}{c}\mathrm{K} \text { - special } \\
\text { limits }\end{array}$ & $0-1250$ & \pm 0.4 & \pm 1.1 \\
\hline
\end{tabular}

\section{RESULTS}

The heat-loss data for the two UVAC3 HCEs, arbitrarily labeled UVAC3 \#1 and UVAC3 \#2, are presented in Table 3 and Fig. 6.

Figure 6 shows that the heat-loss results from each UVAC3 are identical within measurement uncertainty. The heat-loss curve fit in Fig. 6 is within the uncertainty bounds of all data points.

NREL has previously tested Solel's UVAC2 receiver [2]. Figure 7 shows that the UVAC3 receiver has significantly less heat loss than the UVAC2 receiver. 
Table 3. UVAC3 Heat-Loss Results

\begin{tabular}{|c|c|c|c|c|c|c|c|c|c|}
\hline HCE & Test & $\begin{array}{c}\mathrm{T}_{\text {absorber }} \\
\left({ }^{\circ} \mathrm{C}\right)\end{array}$ & $\begin{array}{l}\mathrm{T}_{\text {glass }} \\
\left({ }^{\circ} \mathrm{C}\right)\end{array}$ & $\begin{array}{l}\mathrm{T}_{\text {amb. }} \\
\left({ }^{\circ} \mathrm{C}\right)\end{array}$ & $\begin{array}{c}\mathrm{T}_{\text {abs. }}-\mathrm{T}_{\text {amb. }} \\
\Delta \mathrm{T}\left({ }^{\circ} \mathrm{C}\right)\end{array}$ & $\begin{array}{l}\text { Uncert. } \\
\text { in } \Delta \mathrm{T} \\
\left( \pm^{\circ} \mathrm{C}\right)\end{array}$ & $\begin{array}{l}\text { Heat } \\
\text { loss } \\
(\mathrm{W} / \mathrm{m})\end{array}$ & $\begin{array}{c}\text { Uncert. in } \\
\text { Heat Loss } \\
( \pm \mathrm{W} / \mathrm{m})\end{array}$ & $\begin{array}{c}\text { Date of } \\
\text { Test }\end{array}$ \\
\hline \multirow{7}{*}{$\begin{array}{l}\text { UVAC3 } \\
\text { \#1 }\end{array}$} & 1 & 156.3 & 30.2 & 22.9 & 133.3 & 1.6 & 29.6 & 8.9 & $10 / 4 / 07$ \\
\hline & 2 & 246.9 & 40.5 & 23.0 & 223.9 & 1.6 & 83.0 & 8.9 & $10 / 4 / 07$ \\
\hline & 3 & 309.4 & 52.6 & 23.1 & 286.3 & 1.7 & 146.3 & 9.0 & $10 / 9 / 07$ \\
\hline & 4 & 351.2 & 60.8 & 22.7 & 328.5 & 1.8 & 207.5 & 9.1 & $10 / 9 / 07$ \\
\hline & 5 & 400.1 & 73.1 & 23.1 & 377.1 & 1.9 & 303.1 & 9.2 & $10 / 9 / 07$ \\
\hline & 6 & 201.1 & 34.0 & 22.9 & 178.3 & 1.6 & 53.2 & 8.9 & $10 / 16 / 07$ \\
\hline & 7 & 450.2 & 92.3 & 24.6 & 425.6 & 2.1 & 454.0 & 9.4 & $10 / 17 / 07$ \\
\hline \multirow{8}{*}{$\begin{array}{l}\text { UVAC3 } \\
\text { \#2 }\end{array}$} & 1 & 150.5 & 29.7 & 23.7 & 126.8 & 1.6 & 30.6 & 8.9 & $10 / 18 / 07$ \\
\hline & 2 & 194.9 & 34.0 & 23.8 & 171.2 & 1.6 & 51.1 & 8.9 & $10 / 18 / 07$ \\
\hline & 3 & 249.2 & 40.8 & 22.7 & 226.5 & 1.6 & 88.0 & 9.0 & $10 / 19 / 07$ \\
\hline & 4 & 299.8 & 50.1 & 22.9 & 276.9 & 1.6 & 140.2 & 9.1 & $10 / 19 / 07$ \\
\hline & 5 & 300.4 & 48.4 & 23.5 & 276.9 & 1.6 & 141.2 & 9.1 & $10 / 22 / 07$ \\
\hline & 6 & 349.3 & 59.7 & 24.0 & 325.3 & 1.8 & 212.7 & 9.2 & $10 / 22 / 07$ \\
\hline & 7 & 400.2 & 70.9 & 23.5 & 376.7 & 1.9 & 319.9 & 9.3 & $10 / 23 / 07$ \\
\hline & 8 & 450.0 & 87.7 & 24.2 & 425.8 & 2.1 & 459.3 & 9.4 & $10 / 23 / 07$ \\
\hline
\end{tabular}

UVAC3 Heat Loss Results

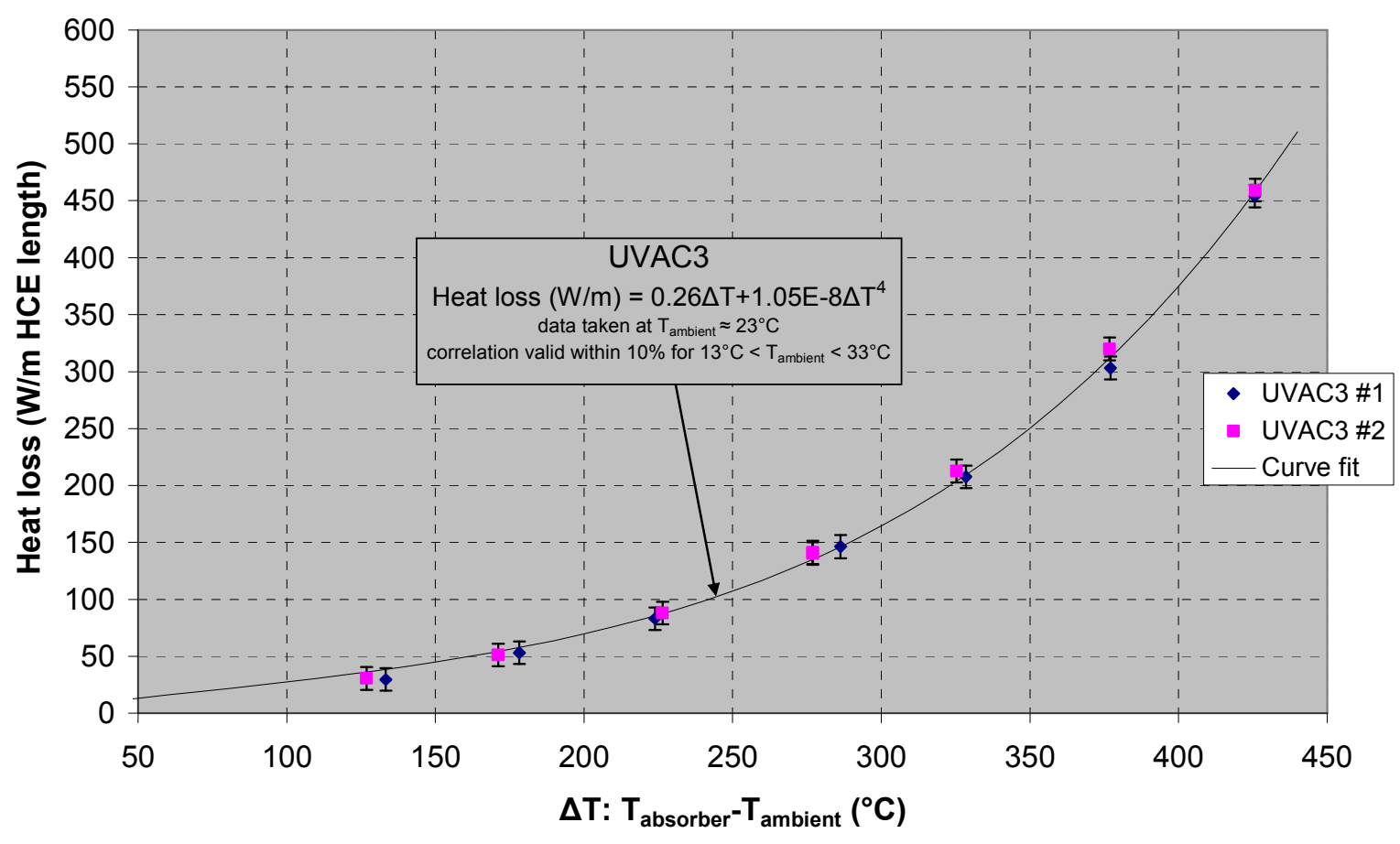

Figure 6. UVAC3 heat-loss results 


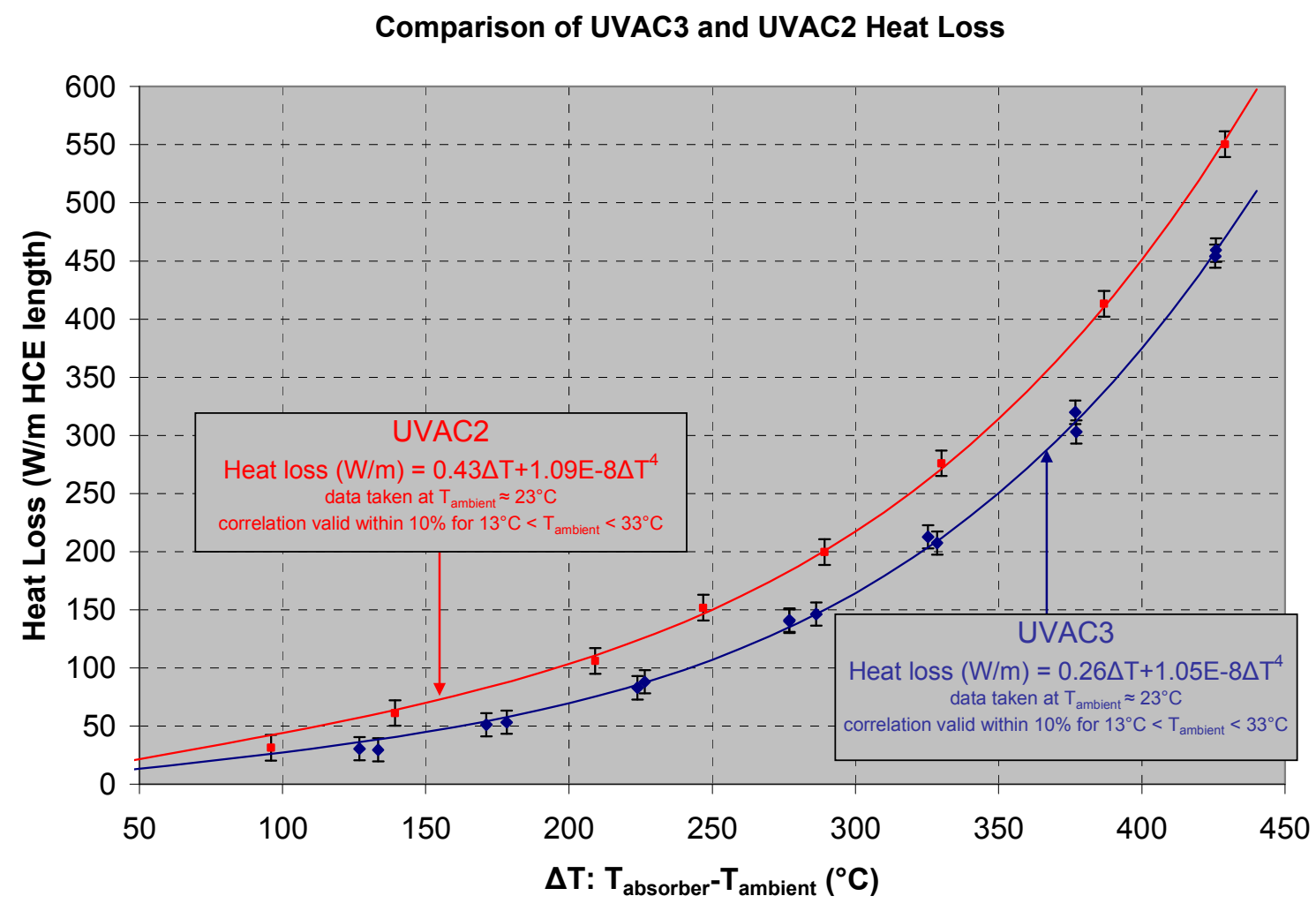

Figure 7. UVAC3 receiver shows less heat loss than UVAC2 receiver

Convention has been to present receiver heat-loss data as a function of the temperature difference between the heat-transfer fluid temperature and ambient temperature $[3,4]$ or the temperature difference between the average absorber temperature and the ambient temperature [2]. Heat losses from evacuated receivers are dominated by radiation heat transfer from the hot absorber surface. For this reason, heat losses from evacuated parabolic trough receivers are better described by the absolute absorber temperature (see Figure 8) than the difference between the absorber or heat-transfer fluid temperature and ambient. 
UVAC3 Heat Loss Results

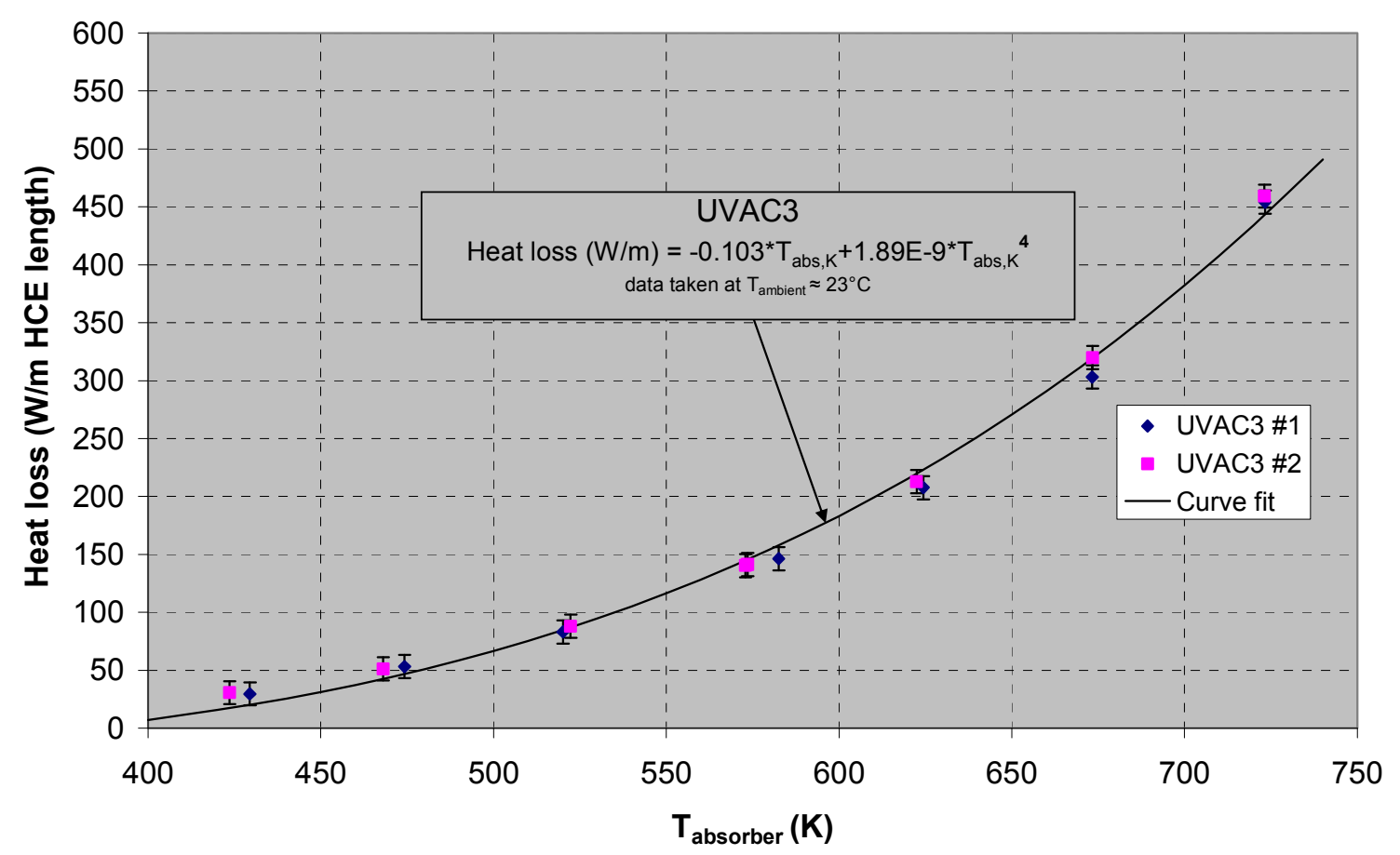

Figure 8. UVAC3 heat loss as a function of absorber temperature

To illustrate how the correlation based on the temperature difference between the absorber and the environment can incorrectly estimate heat loss, consider the following example that uses a validated 1-dimensional heat-transfer model for parabolic trough collector and receiver performance [5]:

A parabolic trough receiver with an absorber spectral emittance curve similar to a UVAC2 receiver is mounted on a collector with a $5 \mathrm{~m}$ aperture and operated under direct-normal radiation of $900 \mathrm{~W} / \mathrm{m}^{2}$ at normal incidence to the sun. Therminol VP1 at $380^{\circ} \mathrm{C}$ is flowing through the receiver's absorber at 140 gallons per minute. If the ambient temperature is $5^{\circ} \mathrm{C}$, the model predicts that the average absorber temperature will be $385^{\circ} \mathrm{C}\left(\Delta \mathrm{T}=380^{\circ} \mathrm{C}\right)$ and the heat loss will be $380 \mathrm{~W} / \mathrm{m}$. If the ambient temperature is $40^{\circ} \mathrm{C}$, the model predicts that the average absorber temperature will be $385^{\circ} \mathrm{C}\left(\Delta \mathrm{T}=345^{\circ} \mathrm{C}\right)$ and the heat loss will be 370 $\mathrm{W} / \mathrm{m}$. Even though the ambient temperature, and therefore the $\Delta \mathrm{T}$, changed by $35^{\circ} \mathrm{C}$ in this example, the heat loss changed by only $10 \mathrm{~W} / \mathrm{m}$. At a $\Delta \mathrm{T}=380^{\circ} \mathrm{C}$, the UVAC2 correlation in Fig. 7 shows heat losses that agree with the model prediction of $380 \mathrm{~W} / \mathrm{m}$. However, if $\Delta \mathrm{T}$ $=345^{\circ} \mathrm{C}$ is used in Fig. 7 for the UVAC2 curve, the correlation predicts heat losses of about $310 \mathrm{~W} / \mathrm{m}$, not $370 \mathrm{~W} / \mathrm{m}$. For this reason, the correlations in the figures should be used with caution - they are most likely accurate to within $10 \%$ if they are used with ambient temperatures within $10^{\circ} \mathrm{C}$ of the temperature at which the data were taken. To predict losses in the solar field, thermal loss coefficients need to be derived from the heat-loss data presented in Table 3 . This will be the subject of a future report. 
Figures 9 and 10 show the data gathered during one steady-state period to make one data point in Table 3 and Fig. 6 . Consider the $400^{\circ} \mathrm{C}$ absorber steady-state period of Test 5 of UVAC 3 \#1 in Table 3 . Figure 8 shows the absorber temperatures and power use during the test period, whereas Fig. 9 shows the simultaneous glass and air temperatures. "N" and "S" in Fig. 8 refer to the north and south sides of the test stand (the thermocouples are numbered from 1 starting at the north end). In Figs. 8 and 9, all values deviate only slightly during the test period, indicating steady state was reached. The heater powers of Fig. 8 are added and divided by the HCE length to determine heat loss per meter receiver length.

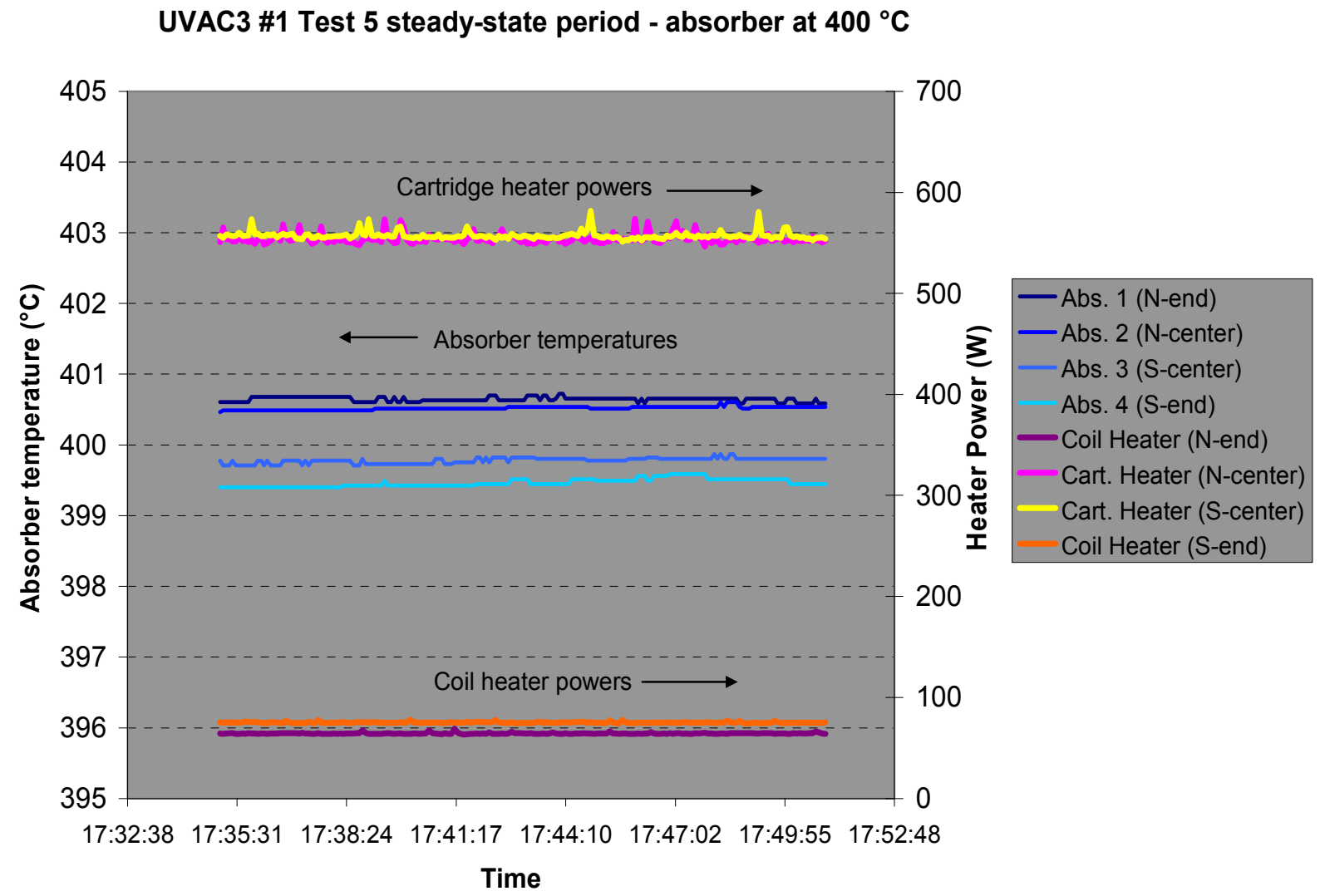

Figure 9. Absorber temperature and power use during Test 5 of UVAC3 \#1 


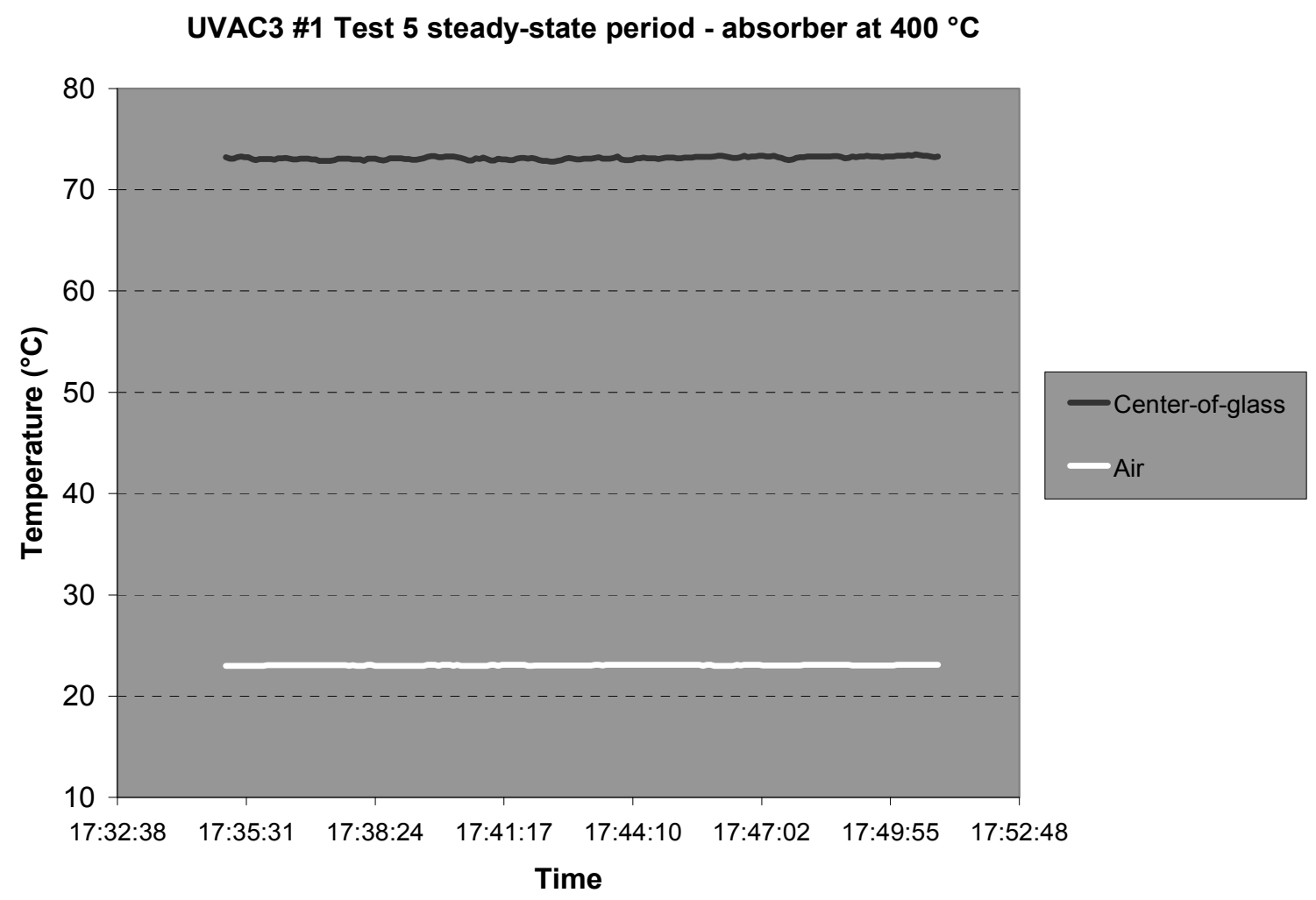

Figure 10. HCE glass and ambient air temperature during Test 5 of UVAC3 \#1

\section{UNCERTAINTY ANALYSIS}

Measurement uncertainty is quantified using the root sum-of-the-squares method described by Dieck [6]. The general expression for $n$ error sources is

$$
\left(e_{R}\right)^{2}=\sum_{i=1}^{n}\left(\frac{\partial R}{\partial e_{i}}\right)^{2} \Delta e_{i}^{2}
$$

The receiver heat-loss equation is

$$
W_{L}=H 1+H 2+H 3+H 4+\frac{k A}{\Delta x}(C u 1-C u 2)+\frac{k A}{\Delta x}(C u 4-C u 3)
$$

where :

$\mathrm{W}_{\mathrm{L}}$ is the heat lost $(\mathrm{W})$

$\mathrm{H} 1$ and $\mathrm{H} 4$ are coil heater powers

$\mathrm{H} 2$ and $\mathrm{H} 3$ are cartridge heater powers

$\mathrm{k}$ is the conductivity of copper

A is the copper pipe's cross - sectional area

$\Delta \mathrm{x}$ is the length between copper thermocouples

$\mathrm{Cu} 1-\mathrm{Cu} 4$ are copper thermocouple temps 
Note that $\mathrm{Cu} 1$ is controlled to equal $\mathrm{Cu} 2$, and $\mathrm{Cu} 4$ is controlled to equal $\mathrm{Cu} 3$, so the contribution due to heat conduction across the end boundary in Eq. (2) is negligible. However, these terms are included in this equation to estimate the uncertainty induced in the results from a potentially non-adiabatic boundary at each end of the HCE.

$$
\begin{aligned}
& \frac{\partial W_{L}}{\partial H 1}=\frac{\partial W_{L}}{\partial H 2}=\frac{\partial W_{L}}{\partial H 3}=\frac{\partial W_{L}}{\partial H 4}=1 \\
& \frac{\partial W_{L}}{\partial C u 1}=\frac{\partial W_{L}}{\partial C u 4}=\frac{k A}{\Delta x} \\
& \frac{\partial W_{L}}{\partial C u 2}=\frac{\partial W_{L}}{\partial C u 3}=-\frac{k A}{\Delta x}
\end{aligned}
$$

Zero error has been assumed for the thermal conductivity, cross-sectional area of the copper pipe, and distance between the copper thermocouples.

Substituting (3), (4), and (5) into (1):

$$
e_{W L}^{2}=\Delta e_{H 1}^{2}+\Delta e_{H 2}^{2}+\Delta e_{H 3}^{2}+\Delta e_{H 4}^{2}+\left(\frac{k A}{\Delta x}\right)^{2}\left(\Delta C u 1^{2}+\Delta C u 2^{2}+\Delta C u 3^{2}+\Delta C u 4^{2}\right)
$$

Equation (6) is calculated for bias and precision errors. Consider the following values for a $400^{\circ} \mathrm{C}$ absorber heat-loss measurement:

$$
\begin{aligned}
& \Delta e_{H 1 \text { bias }}=\Delta e_{H 4 b i a s}=2.5 \mathrm{~W} \\
& \Delta e_{H 2 \text { bias }}=\Delta e_{\text {H3bias }}=25 \mathrm{~W} \\
& \Delta C u 1_{\text {bias }}=\Delta C u 2_{\text {bias }}=\Delta C u 3_{\text {bias }}=\Delta C u 4_{\text {bias }} \approx 1.8^{\circ} \mathrm{C} \\
& k \approx 380 \frac{W}{m-K} \quad A=3.5 \times 10^{-4} m^{2} \quad \Delta x=0.04 \mathrm{~m} \\
& \Delta e_{H 1 \text { prec }}=\Delta e_{H 4 \text { prec }}=0.04 \mathrm{~W} \\
& \Delta e_{H 2 \text { prec }}=\Delta e_{H 3 \text { prec }}=0.4 \mathrm{~W} \\
& \Delta C u 1_{\text {prec }}=\Delta C u 2_{\text {prec }}=\Delta C u 3_{\text {prec }}=\Delta C u 4_{\text {prec }} \approx 0.005^{\circ} \mathrm{C} \\
& \text { Uncert }_{\text {bias }}{ }^{2}=2.5^{2}+25^{2}+25^{2}+2.5^{2}+\left(\frac{380 * 3.5 \times 10^{-4}}{0.04}\right)^{2}\left(1.8^{2}+1.8^{2}+1.8^{2}+1.8^{2}\right) \approx 1400 \mathrm{~W} \\
& \text { Uncert }_{\text {bias }}=\sqrt{1400} \approx 37 \mathrm{~W} \\
& \text { Uncert }_{\text {prec }}{ }^{2}=0.04^{2}+0.4^{2}+0.4^{2}+0.04^{2}+\left(\frac{380 * 3.5 \times 10^{-4}}{0.02}\right)^{2}\left(4 *+0.005^{2}\right) \approx 0.1 \mathrm{~W} \text {. } \\
& \text { Uncert }_{\text {prec }}=\sqrt{0.33}=0.6 \mathrm{~W} \\
& \text { Uncert }_{\text {total }}= \pm \sqrt{\left(\text { Uncert }_{\text {bias }}{ }^{2}+\left(2 * \text { Uncert }_{\text {prec }}\right)^{2}\right)}= \pm 37 \mathrm{~W}
\end{aligned}
$$


Normalizing per meter length:

$$
\text { Uncert }_{\text {Total }}=\left(\frac{37 \mathrm{~W}}{4 \mathrm{~m}}\right) \approx \pm 9 \frac{\mathrm{W}}{\mathrm{m}}
$$

\section{CONCLUSION}

NREL has completed heat-loss testing on two of Solel's UVAC3 parabolic trough receivers. The receivers showed identical heat losses within experimental uncertainty. Normalized per meter of receiver length, the heat losses are 130,200,310, and $460 \mathrm{~W} / \mathrm{m}$ at average absorber temperatures of $300^{\circ}, 350^{\circ}, 400^{\circ}$, and $450^{\circ} \mathrm{C}$, respectively. Experimental uncertainty is about $\pm 10 \mathrm{~W} / \mathrm{m}$. A correlation was developed to predict receiver heat loss as a function of the difference in ${ }^{\circ} \mathrm{C}$ between the average absorber temperature and ambient temperature. This correlation is:

$$
\text { UVAC3 heat loss }(\mathrm{W} / \mathrm{m})=0.26 * \Delta \mathrm{T}+1.05 * 10^{-8} * \Delta \mathrm{T}^{4}
$$

This correlation will be accurate within $10 \%$ for ambient temperatures between $13^{\circ}$ and $33^{\circ} \mathrm{C}$. UVAC 3 heat losses were also compared to previous-generation UVAC2 heat losses. The UVAC3 receiver shows significantly lower heat loss: $310 \mathrm{vs.} 380 \mathrm{~W} / \mathrm{m}$ at $400^{\circ} \mathrm{C}$, which is a $20 \%$ reduction in heat loss.

Receiver performance depends on more than just heat losses. Optical-efficiency testing is required to create a collector/receiver efficiency curve that estimates the heat gain to the heattransfer fluid flowing within the receiver. Heat losses, as tested in this report, serve to reduce the heat gain to the heat-transfer fluid and thereby decrease collector/receiver efficiency. Determination of loss coefficients to predict solar field performance will be the subject of a future report.

\section{ACKNOWLEDGMENTS}

The authors would like to acknowledge Hank Price, formerly with the National Renewable Energy Laboratory (NREL) and now with Solucar; Judy Netter and Calvin Feik from NREL; and Tim Moss at Sandia National Laboratories for assistance with the design and construction of the test stand. 


\section{REFERENCES}

[1] Kearney, D.; Price, H., "Advances in Parabolic Trough Solar Power Technology," Advances in Solar Energy. Vol 16, Kreith, F., Goswami, D.Y. (Eds.), ASES, Boulder, Colorado, 2005.

[2] Burkholder, F.; Price, H.; Kutscher, C.; Brandemuehl, M.; Netter, J., "Parabolic Trough Receiver Thermal Testing," Proceedings of the ASME Energy Sustainability Conference, Long Beach, California, June 27-30, 2007.

[3] Dudley, V.; Kolb, G.; Mahoney, A.R.; Mancini, T.; Matthews, C.; Sloan, M.; Kearney, D., "Test Results SEGS LS-2 Solar Collector," SAND94-1884, December 1994.

[4] Moss, T.; Brousseau, D., "Test Results of a Schott Trough Receiver using a LS-2 Collector," Proceedings of ISEC: ASME 2005, Orlando, Florida, August 6-12, 2005

[5] Forristall, R., "EES Heat Transfer Model for Solar Receiver Performance," Proceedings of ISEC, Solar 2004, Portland, Oregon, July 11-14, 2004.

[6] Dieck, R.H., Measurement Uncertainty, Methods and Applications. North Carolina: Instrument Society of America, 1992 


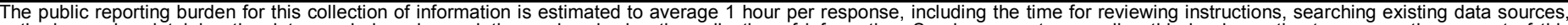

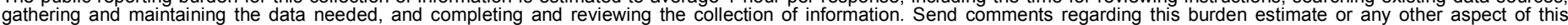

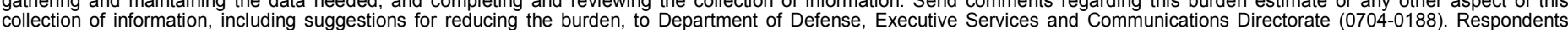

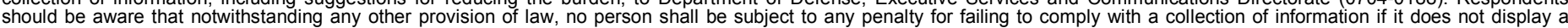

should be aware that notwithstanding

PLEASE DO NOT RETURN YOUR FORM TO THE ABOVE ORGANIZATION.

\begin{tabular}{l|l|l|l|} 
1. REPORT DATE $(D D-M M-Y Y Y Y)$ & 2. & REPORT TYPE & 3. DATES COVERED (FrOm - TO)
\end{tabular} January 2008

Technical report

4. TITLE AND SUBTITLE
Heat-Loss Testing of Solel's UVAC3 Parabolic Trough Receiver

5a. CONTRACT NUMBER

DE-AC36-99-GO10337

5b. GRANT NUMBER

5c. PROGRAM ELEMENT NUMBER

6. AUTHOR(S)

F. Burkholder and C. Kutscher

5d. PROJECT NUMBER

NREL/TP-550-42394

5e. TASK NUMBER

CP07.3101

5f. WORK UNIT NUMBER

7. PERFORMING ORGANIZATION NAME(S) AND ADDRESS(ES)

National Renewable Energy Laboratory

1617 Cole Blvd.

Golden, CO 80401-3393

9. SPONSORING/MONITORING AGENCY NAME(S) AND ADDRESS(ES)

10. SPONSOR/MONITOR'S ACRONYM(S)

NREL

11. SPONSORING/MONITORING AGENCY REPORT NUMBER

12. DISTRIBUTION AVAILABILITY STATEMENT

National Technical Information Service

U.S. Department of Commerce

5285 Port Royal Road

Springfield, VA 22161

13. SUPPLEMENTARY NOTES

14. ABSTRACT (Maximum 200 Words)

NREL researchers completed heat-loss testing on two of Solel's UVAC3 parabolic trough receivers. The receivers showed identical heat losses within experimental uncertainty. Normalized per meter of receiver length, heat losses are about $130,200,310$, and $460 \mathrm{~W} / \mathrm{m}$ at average absorber temperatures of $300^{\circ}, 350^{\circ}, 400^{\circ}$, and $450^{\circ} \mathrm{C}$, respectively. Experimental uncertainty is about $\pm 10 \mathrm{~W} / \mathrm{m}$. We developed a correlation to predict receiver heat loss as a function of the difference in ${ }^{\circ} \mathrm{C}$ between the average absorber temperature and ambient temperature. This correlation is the following: UVAC3 heat loss $(\mathrm{W} / \mathrm{m})=0.26{ }^{*} \Delta \mathrm{T}+1.05^{*} 10-8 * \Delta \mathrm{T} 4$. Care must be taken to apply this correlation only within context. The correlation was derived with ambient temperatures of about $23^{\circ} \mathrm{C}, \mathrm{and}^{\circ}$ it should not be used to predict heat losses at ambient temperatures more or less than $10^{\circ} \mathrm{C}$ from this value. UVAC3 heat losses were compared to heat losses from UVAC2, the previous generation of receiver. The UVAC3 receiver shows significantly lower heat loss: $310 \mathrm{vs.} 380 \mathrm{~W} / \mathrm{m}$ at $400^{\circ} \mathrm{C}$, which is a $20 \%$ reduction in heat loss. It is important to note that receiver performance depends on more than just heat losses. Optical efficiency testing is required to create a collector/receiver efficiency curve that estimates the heat gain to the heat-transfer fluid flowing within the receiver. Heat losses, as tested in this report, serve to reduce the heat gain to the heat-transfer fluid and therefore reduce the collector/receiver efficiency.

\section{SUBJECT TERMS}

CSP ; parabolic trough ; receiver ; heat-loss testing ; correlation ; UVAC3

\begin{tabular}{|l|l|l|l|l|}
\hline \multicolumn{3}{|l|}{ 16. SECURITY CLASSIFICATION OF: } & 17. LIMITATION \\
OF ABSTRACT & $\begin{array}{c}\text { 18. NUMBER } \\
\text { OF PAGES }\end{array}$ \\
\hline $\begin{array}{l}\text { a. REPORT } \\
\text { Unclassified }\end{array}$ & $\begin{array}{c}\text { b. ABSTRACT } \\
\text { Unclassified }\end{array}$ & $\begin{array}{l}\text { c. THIS PAGE } \\
\text { Unclassified }\end{array}$ & UL & \\
\end{tabular}

19a. NAME OF RESPONSIBLE PERSON
19b. TELEPHONE NUMBER (Include area code)

